\title{
The Influence of the Size of the Board of Commissioners, Size of the Board of Directors, Size of the Audit Committee, and Company Size on Banking Performance at Indonesian Regional Development Banks in 2015-2020
}

\author{
Ifadatul Musdalifah $^{1 *}$, Risdiana Himmati ${ }^{2}$ \\ ${ }^{1}$ Islamic Banking, Faculty of Islamic Economics and Business, UIN Sayyid Ali Rahmatullah, \\ Tulungagung \\ ${ }^{2}$ Islamic business management, Faculty of Islamic Economics and Business, UIN Sayyid Ali \\ Rahmatullah, Tulungagung
}

\begin{abstract}
This research is motivated by the fact that the ROA of Regional Development Banks in 2015-2019 fluctuated, this shows that there are factors that influence it, one of which is Good Corporate Governance . By implementing Good Corporate Governanceand supported by the mechanism will improve banking performance. Banking performance is influenced by the size of the Board of Commissioners, the size of the Board of Directors, the size of the Audit Committee, and the size of the company. The formulation of the problem in this study is how do the size of the board of commissioners, the size of the board of directors, the size of the audit committee, and the size of the company affect banking performance at the regional development banks of Indonesia in 2015-2020?. By using a quantitative approach and the type of secondary data as well as the number of samples of 12 banks were taken using purposive sampling technique . Data processing using E-Views 10 with panel data regression analysis techniques. The results of this study are partially the size of the Board of Commissioners, the size of the Board of Directors, and the size of the company have no significant effect on banking performance. Meanwhile, the size of the Audit Committee has a negative and significant effect on banking performance. Simultaneously the size of the Board of Commissioners, the size of the Board of Directors, the size of the Audit Committee, and the size of the company have a significant effect on banking performance.
\end{abstract}

\section{Preliminary}

In general, the role of the bank is intended to support the implementation of economic development in order to improve the standard of living of the community. The Regional Development Bank (BPD) aims to facilitate the process of equitable development to all regions in the country of Indonesia in its efforts to raise the standard of living of the

* Corresponding author: ifadatulmusdalifah@gmail.com 
community so that BPD is required to always improve the role and performance of its company.

Firm size is defined as one of the various factors that can have an influence on banking performance and this can be measured using total assets. Companies whose total assets are increasing indicate that the size of the company is getting bigger and it is possible that the company's financial performance will also be greater.

Regional Development Bank ROA percentage data in 2015-2019.

Chart. 1. Graph of Return On Assets (ROA) Percentage

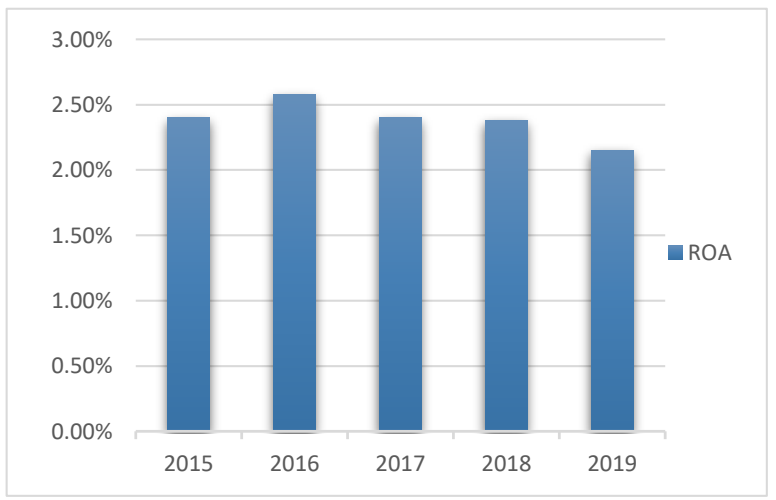

Source: Indonesian Banking Statistics OJK

Data on the percentage of ROA at BPD in 2015-2019 in graph 1.1 shows that in 20152019 banking performance fluctuated. This fact shows that there are factors that influence fluctuations in ROA, one of which is Corporate Governance. The key to success to improve company performance is to implement GCG within the company to gain long-term profits and be able to compete in international business (Sudarmanto; \& Dkk, 2021). Companies that implement GCG require a GCG mechanism, including the Board of Commissioners, the Audit Committee and the Board of Directors.

It is necessary for the Board of Commissioners to oversee the implementation of the board of directors' policies and monitor the effectiveness of the implementation of Good Corporate Governance. The Board of Commissioners which has a small size will later be able to be more optimal in carrying out supervisory duties compared to what is carried out by a larger Board of Commissioners. Board of Commissioners with a large size is considered less able to carry out their duties because it is difficult to communicate, regulate and make decisions (Pricilia \& Susanto, 2017). According to research (Rahmawati, IA, Rikumahu, Brady., and Dillak, 2017) reveals that the size of the Board of Commissioners contributes significantly and positively to the ROA variable. While research from (Dewi et al., 2018) found that the size of the Board of Commissioners does not affect the performance of the company under study.

The Board of Directors is a determining component in formulating strategies that will be used by the company, the Board of Directors also determines what type of strategy the company will use for the short or long term. With this many members of the Board of Directors, it will have an impact on monitoring the company's performance, so that it will improve and be controlled, so that the resulting profitability will be better and improve company performance. According to research (Akpan, Emmanuel S. B Hodo, 2012) 
it is known that the size of the Board of Directors affects the improvement of banking performance. While research (Dany Yadnyapawita \& Aryista Dewi, 2020) it is known that the Board of Directors does not contribute a statistically significant influence on the company's performance, this is because as management the Board of Directors always wants to improve the company's performance.

The Audit Committee has the task of supervising the company's internal auditing, risk management, financial reporting processes, and also the implementation of GCG in the company (Irma, 2019). With more and more members of the Audit Committee, it is expected to have an impact on increasing company performance. With more and more members of the Audit Committee, it is expected to have an impact on increasing company performance. According to research (Sari et al., 2020) explaining that the number of members of the Audit Committee has an influence on the company's performance, this is due to the fact that the Audit Committee is tasked with facilitating the Board of Commissioners in carrying out monitoring of the management in carrying out the financial reporting process which is intended to can increase the credibility of the resulting financial reporting.

Based on these problems, the authors are interested in researching "The Influence of Board of Commissioners Size, Board of Directors Size, Audit Committee Size, and Company Size on Banking Performance at Indonesian Regional Development Banks in 20152020". With the formulation of the problem, namely How does the size of the board of commissioners, the size of the board of directors, the size of the audit committee, and the size of the company affect banking performance at regional development banks? the significance of the size of the Board of Directors on banking performance, H3: there is a significant effect of the size of the Audit Committee on banking performance, H1: there is a significant effect of company size on banking performance.

\section{Theoritical Basis}

\subsection{Agency Theory}

The basic concept of agency theory lies in agency problems that arise when the company's management is separated from its ownership. The company is a role that provides opportunities for each different member to contribute as capital, skills, and labor to maximize profits in the long term. The members who contribute capital are called principals, while those who contribute skills and labor are called agents. The existence of these two participants raises problems regarding the roles that must be formed in order to harmonize the differences in interests between the two (Henrawaty, 2017).

\subsection{Stakeholder Theory}

Stakeholder theory asserts that in addition to the system and structure used by corporate organs to further develop business performance and corporate responsibility by considering stakeholders, the company is not a company that operates solely for its own welfare. However, the company's goal is to meet the needs of its stakeholders. Stakeholders affect the survival of the company, and each company has different stakeholders (Suharyani et al., 2019).

\subsection{Board of Commissioners Size}


The size of the Board of Commissioners is the number of the Board of Commissioners in a particular company. The size of the Board of Commissioners can be calculated using the formula:

\section{$\Sigma$ Anggota Dewan Komisaris}

\subsection{Board of Directors Size}

The size of the Board of Directors can be defined as the number of Board of Directors in a particular company. The size of the Board of Directors can be calculated using the formula:

\section{$\Sigma$ Anggota Dewan Direksi}

\subsection{Audit Committee Size}

The size of this company can be defined as scale and value, which means that the size of the company can be estimated by total assets, stock prices, log size, and others. The size of the company is reflected in the total assets it has, with large company assets, thus the size of the company is also large, and vice versa. This definition reveals that the size of the company is possible to be evaluated from the total assets it has (Wufron, 2017) .

\subsection{Banking Performance}

Banking performance can be defined by the results that the bank has achieved in carrying out the management of the available resources in an efficient and effective manner in order to meet or achieve various goals that have been previously determined and determined. One of the various proportions used in viewing the performance of the banking sector is in the form of Return On Assets (ROA). With a high ROA, thus the level of achievement of company profits and the impact on improving banking performance is also large.

\subsection{The Relationship between Board of Commissioners Size and Banking Performance}

Theoretically, the core of GCG is the Board of Commissioners who is responsible for ensuring the implementation of the company's strategy, requiring financial accountability, and supervising the management of the company. This is important considering the importance of management in completing earnings management which has an impact on low investor confidence. The higher the number of individual members of the Board of Commissioners, this will make it easier for the CEO to exercise control and this will make the controlling process carried out by the CEO easier and in supervising management activities can be more effective (Puspitowati \& Mulya, 2014) .

\subsection{The Relationship between Board of Directors Size and Banking Performance}

Theoretically, the Board of Directors functions to handle companies selected by investors for the GMS representing the interests of investors. Obligations and responsibilities in managing the company collegially. The number of members of the Board of Directors made adjustments based on the complexity of the company while focusing on the adequacy of making decisions in an efficient and effective manner, quickly and precisely and able to 
act independently. The more the Board of Directors, the type of supervision given to the company's performance is increasing, the company's performance is controlled, it can create great profitability so that the company's performance will increase (Wijayanti \& Mutmaimah, 2012).

\subsection{Relationship between Audit Committee Size and Banking Performance}

The Audit Committee can be defined as several people selected by the Board of Commissioners who are responsible for overseeing the financial reporting and exposure process. The reality is that it can be relied upon to create a certain added value for a particular company. Within the basic framework of Corporate Governance, the application of the principles of Corporate Governance depends on three main pillars, including strong internal control, external audit that provides feedback, independent internal audit, and information on the effectiveness of internal control processes within the company. Effectiveness and optimizing the role of the Audit Committee as an augmentation of the Board of Commissioners to assist the effectiveness of the three pillars (Wijayanti \& Mutmaimah, 2012). The higher the number of members of the Audit Committee, the more it is believed that the performance of the Audit Committee will be easier to ensure the quality of the performance of the financial statements presented by management (Puspitowati \& Mulya, 2014, p. 225).

\subsection{The Relationship between Firm Size and Banking Performance}

Company size is a description for large or small companies which is reflected in the total value of the company's assets in the year-end balance sheet. When the company has high total assets, this indicates that the company has achieved progress or prosperity. According to Sembiring, generally companies with relatively high total assets can work more efficiently

than firms with lower total assets. Companies that have higher total assets will be better able to generate high profitability. The size of the company will have an impact on the company's financing structure. As a result, companies tend to require higher funding than small companies (Wijayanti \& Mutmaimah, 2012).

\subsection{Previous Research}

Referring to the results of the research conducted (Rahmawati, IA, Rikumahu, Brady., and Dillak, 2017) concluded that the variable size of the Board of Commissioners and the Board of Directors contributed significantly and partially positive influence on the ROA variable partially. Meanwhile, the CSR and Audit Committee variables did not contribute partially to the ROA variable.

Referring to the results of the research conducted (Alex \& Ngaba, 2018) in this research, the aim is to be able to find out or understand the influence of company size on the financial performance variable in Commercial Banks in Kenya, it can be concluded that there is a significant relationship involving the variables firm size with financial performance variable. This bank with many branches, high capital base, high customer deposits, and high loan book has a positive impact and high ROA compared to banks with small loan book, small capital base, small customer deposits, and also a small number of branches. . 
Referring to the statement put forward (Sari et al., 2020) the research aims to determine the effect of the variable Company Size, Managerial Ownership and Audit Committee on the financial performance variable, in which the results of this study indicate that the leverage variable, Managerial Ownership and Committee Audit contributes to the financial performance variable, while the firm size variable does not contribute to the financial performance variable.

3. Research methodology

\subsection{Research Approach and Type}

To carry out this research, the research approach used is in the form of quantitative and while the type of research is associative research, the research carried out is intended to be able to determine the relationship between the variables of the research being carried out research.

\subsection{Population}

The population of this study is in the form of Regional Development Banks in Indonesia and registered with the Financial Services Authority. The number of Regional Development Banks used as a population is 26 banks.

\subsection{Sampling Technique}

In this study, the data collection of this research is by using purposive sampling technique, the research sampling technique is to use the characteristics or criteria specified. The following are the criteria for the research sample, as below:

a. Regional Development Banks (BPD) registered with the Financial Services Authority (OJK) for the 2015-2020 period.

b. Regional Development Banks (BPD) which publish a complete Annual Report for the 2015-2020 period.

\subsection{Sample}

By using purposive sampling in sampling, obtained a population of 12 Regional Development Banks.

\subsection{Data collection technique}

For this study, the technique for collecting research data is to use documentation techniques from the annual reporting of the Regional Development Banks in Indonesia for 2015-2020 which are obtained from the sample banks' websites.

\subsection{Data Types and Data Sources}

This study uses secondary data types (Mashudi et al., 2021) and the source of the data obtained is based on the 2015-2020 annual report obtained from the official website of the Development Bank in Indonesia.

\subsection{Data analysis technique}

\subsubsection{Panel Data Regression Test}

Panel data is defined as a combination of cross section data with time series. The panel regression model is expressed in the form of an equation: $\mathrm{T}_{\mathrm{ti}}=+\mathrm{ib}{ }_{1} \mathrm{X}_{1 \mathrm{ti}}+\mathrm{b}_{2} \mathrm{X}_{2 \mathrm{ti}}+\mathrm{b}_{3} \mathrm{X}_{3 \mathrm{ti}}+\mathrm{b}_{4} \mathrm{X}_{4 \mathrm{ti}}+\mathrm{e}$

\footnotetext{
Information:

$\mathrm{Y}=$ Dependent Variable

$=$ Constant

$\mathrm{X}_{1}=$ Size of the Board of Commissioners

$\mathrm{X}_{2}=$ Size of the Board of Directors

$\mathrm{X}_{3}=$ Audit Committee Size

$\mathrm{X}_{4}=$ Company Size

$\mathrm{E}=$ error

$\mathrm{I}=$ Company
} 
$\mathrm{T}=$ Year Time Period

\subsubsection{Model Estimation on Panet Data Regression}

There are three approach models in panel data regression as below:

a. The Commond Effect Model (CEM) is a very simple research method. This model has a weakness, namely the inconsistency of the model with the original condition. The condition of each object may be different and from time to time its condition may differ.

b. Fixed Effect Model (FEM) The difficulty of meeting the catch and slope assumptions is one of the many difficulties or complications in the panel data procedure. To overcome this, in a data panel by including a dummy variable (dummy variable) in order to facilitate the differences in parameter values, both time series data and also cross section data .

c. Random Effect Model (REM) REM is useful in order to solve the various weaknesses contained in the FEM modeling by using false variables, thus this model creates an uncertainty. Using this false variable will be able to minimize the independent level and which in the end will be able to minimize the efficiency of the parameters to be estimated.

\section{a. Chow Test}

\subsubsection{Stages in the Data Panel}

This Chow Test is useful in order to understand the model better, between the Fixed Effect Model (FEM) and the Common Effect Model (CEM).

$H_{0}=$ Comment Effect Model (CEM)

$H_{1}=$ Fixed Effect Model (FEM) If the cross-section probability value is >

0.05 , then $\mathrm{H}_{\mathrm{O}}$ is accepted, hereby the model used is the Common Effect

Model (CEM) and vice versa.

b. Hausman Test

Hausman Test is used to better determine the model between the Fixed Effect Model (FEM) and the Random Effect Model (REM).

$\mathrm{H}_{0}=$ Random Effect Model (REM)

$\mathrm{H}_{1}=$ Fixed Effect Model (FEM) If the cross-section probability value is $>0.05$, with $\mathrm{H}_{0}$ is accepted, then the model used is the Random Effect Model (REM). However, if the value of the probability of a cross-section of $<0.05$, with $\mathrm{H}_{0}$ is rejected, so that the model used is a model Fixed Effect Model (FEM).

\section{Research methodology}

\subsection{Model Estimation on Panel Data Regression}

a. Chow test

Based on the results of the Chow test, the chi-square probability value is 0.0261 $<0.05$. So that the results obtained by FEM are more precise than CEM.

b. Hausman test 
Based on the results of the Hausman test, it shows that the chi-square probability value is $0.1868>0.05$. So that the conclusion obtained by REM is more appropriate to use in this panel data regression than FEM.

\subsection{Classic assumption test}

a. Normality test

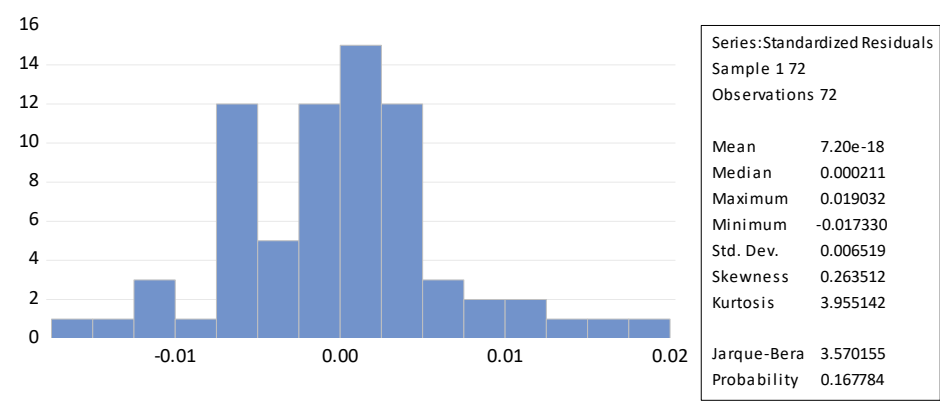

Source: Results of data processing by researchers using E-Views

Chart. 2. Normality Test Results

Based on the results of the normality test, it is known that the JarqueBera probability value of 0.1678 is greater than the significance level (0.05), so it can be concluded that the residuals are normally distributed.

\section{b. Heteroscedasticity Test}

Based on the results of the heteroscedasticity test using the white test, it is known that the results of the white test show a p-value of 0.4486 which is greater than the significance level (0.05). It was concluded that $\mathrm{H}_{0}$ is received, which means that the variant is the same, or there are no symptoms heteroskedastisitas.

\subsection{Hypothesis testing}

a. $\quad$ test

Table. 1. $t$ test results

\begin{tabular}{|c|c|c|c|c|}
\hline Variable & Coefficient & Std. Error & t-count & Probability \\
\hline $\mathrm{X}_{1}$ & -0.000410 & 0.000890 & -0.460812 & 0.6464 \\
\hline $\mathrm{X}_{2}$ & -0.000338 & 0.000959 & -0.352811 & 0.7253 \\
\hline $\mathrm{X}_{3}$ & -0.001994 & 0.000779 & -2.558916 & 0.0128 \\
\hline $\mathrm{X}_{4}$ & -4.255445 & 3.453775 & -1.232114 & 0.2222 \\
\hline
\end{tabular}

Source: Results of data processing with Eviews 10, 2021 
Based on Table 1, it can be described as follows:

\section{Board of Commissioners Size}

From the table of t-test results, it can be seen that the $t$-count value is -0.460812 , meaning that the $\mathrm{t}$-count is smaller than the t-table. In addition, when viewed from the probability, $t$ test results showed that the probability value of the variable $X_{1}$ at $0.6464>0.05$ significance level. So the conclusion obtained is that the variable size of the Board of Commissioners partially does not have a positive and significant effect on banking performance. This may occur due to the lack of maximum performance of the Board of Commissioners in carrying out their duties such as supervising the running of the company and ensuring that the Board of Directors carries out their obligations properly in accordance with the company's objectives, namely improving company performance. The increasing number of members of the Board of Commissioners can lead to agency problems that affect the company's performance.

In line with research from (Sukandar, 2014) that the size of the commissioner does not contribute significantly to financial performance. The number of members of the Board of Commissioners is not necessarily the company will have a high performance as well. Reinforced by current conditions where at the Maluku Regional Development Bank, in the second quarter of 30 June 2020 the number of the Board of Commissioners consists of 2, while in the second quarter of 30 June 2021 the number of the Board of Commissioners is 3 people. Judging from the financial reports in the second quarter of June 30, 2020, it is known that ROA is $3.17 \%$, while in the second quarter of June 30, 2021, it has decreased, namely ROA obtained by $2.85 \%$. With the addition of the number of members of the Board of Commissioners, BPD DKI actually experienced a decrease in its performance.

\section{Board of Directors Size}

From the table of t-test results, it can be seen that the $t$-count value is -0.352811 , meaning that the t-count is smaller than the t-table. In addition, when viewed from the probability value, the results of the $t$ test show the probability value for the $\mathrm{X}_{2}$ variable is $0.7253>$ a significance level of 0.05 . It is concluded that partially does not have a positive and significant effect on banking performance. This could be due to the increasing number of the Board of Commissioners which will result in problems in communication and in decision making, thus hampering the improvement of banking performance. More and more members of the Board of Directors will cause agency problems such as excessive control over the company's operational activities, this is what causes the size of the Board of Directors to not contribute to the impact of banking performance.

This is in line with research (Dany Yadnyapawita \& Aryista Dewi, 2020) which states that the Board of Directors does not statistically have a significant influence on the company's performance, because the Board of Directors as management always wants to improve the company's performance. Reinforced by current conditions where at the Aceh Regional Development Bank, in the second quarter of 30 June 2020 the number of the Board of Directors consists of 5 while in the second quarter of 30 June 2021 the number of the Board of Directors is 4 people. Judging from the financial reports in the second quarter of 30 June 2020, it is known that the ROA was $1.67 \%$, while in the second quarter of 30 June 2021 there was an increase, namely the ROA was obtained by $1.70 \%$. With the reduction in the number of members of the Board of Directors, BPD Aceh actually experienced an increase in its performance. 


\section{Audit Committee Size}

From the table of t-test results, it can be seen that the t-count value is -2.558916 , meaning that the $\mathrm{t}$-count is smaller than the $\mathrm{t}$-table. In addition, when viewed from the probability value on the $\mathrm{X}_{3}$ variable, it is $0.0128<0.05$ significance level. It is concluded that partially has a negative and significant influence on banking performance at the Indonesian Regional Development Bank in 2015-2020. The increasing number of members of the Audit Committee can cause problems in the distribution of responsibilities and the possibility of miscommunication and will experience difficulties in the decision-making process so that the performance of the Audit Committee becomes ineffective and has an impact on the decline in banking performance. Vice versa.

The results of research from (Irma, 2019) that the Audit Committee has a significant influence on financial performance in a negative direction which means that the more the number of the Audit Committee can result in a decrease in financial performance. The more the number of the Audit Committee, the more supervision and control that will be carried out, so that it will result in a lot of consideration in the decisions of the Audit Committee with varying educational backgrounds. Not all Audit Committees have expertise in accounting and finance, so that it has an impact on the supervision of financial statements and may contribute to the decline in ROA. Judging from the current conditions where the Maluku Regional Development Bank, in the second quarter of 30 June 2020 the number of the Audit Committee consisted of 2 while in the second quarter of 30 June 2021 the number of the Audit Committee was 3 people. Judging from the financial reports in the second quarter of June 30, 2020, it is known that the ROA is $3.17 \% \%$, while in the second quarter of June 30, 2021, it has increased, namely the ROA obtained by $2.85 \% \%$. With the addition of the number of members of the Board of Directors, BPD Maluku actually experienced a decline in its performance.

\section{Company Size}

From the table of t-test results, it can be seen that the t-count value is -1.232114 , meaning that the $\mathrm{t}$-count is smaller than the t-table. In addition, when viewed from the probability value on the $\mathrm{X}_{4}$ variable, it is $0.2222>$ a significance level of 0.05 . It was concluded that partially did not have a positive and significant effect on banking performance at the Indonesian Regional Development Bank in 2015-2020. The possible cause is because in this study the benchmark for company size is total assets. So total assets are not the right benchmark to measure the size of the company. A small company does not determine the ROA owned is also small. In assessing the scale of the company there are many factors that need to be considered. One of them is how to get maximum profit by managing the company's assets effectively and efficiently.

In line with research from (Sari et al., 2020) revealed that the variable size of this company can be measured using total assets, it cannot determine the financial performance of the company it owns is good. This is due to the fact that the high size of the company will not be in line with good sales management. Judging from the current conditions where at BPD Central Java, on December 31, 2020 the total assets obtained were Rp. 73,106,134 (in millions of rupiah), while on June 30, 2021 the total assets acquired were Rp. 81,446,169 (in millions of rupiah). Judging from the financial statements on December 31, 2020, it is known that ROA is $2.03 \%$, while in the second quarter of June 30, 2021, it has increased, namely ROA was obtained by $2.61 \%$. The size of the company at the Central Java Regional 
Development Bank as seen from the total assets has increased and the company's performance has also increased.

At the Lampung Regional Development Bank, from the financial statements it can be seen that on December 31, 2020 the total assets obtained were Rp. 8,072,135 (in millions of rupiah), while on June 30, 2021 the total assets acquired were Rp. 10,283,580 (in millions of rupiah). Judging from the financial reports on December 31,2020 , it is known that ROA was $2.81 \%$, while in the second quarter of June 30, 2021, it experienced a decrease, namely ROA was obtained by $2.36 \%$. The size of the company at the Lampung Regional Development Bank as seen from the total assets has increased but the company's performance has decreased.

\section{b. F Uji test}

From the results of the $\mathrm{F}$ test, it can be seen that the $\mathrm{F}_{\text {table }}$ shows a number of 2.629987 obtained from the calculation of the $\mathrm{F}_{\text {table }}$ with $\mathrm{df}_{1}=\mathrm{k}-1=4-1=3$, and $\mathrm{df}_{2}=$ $\mathrm{nk}=360-4=356$, then the table $\mathrm{F}_{\text {table }}$ shows the number 2.629987. So that $\mathrm{F}_{\text {coun }} 5.021910>\mathrm{F}_{\text {tabl }} 2.629987$, then $\mathrm{H}_{1 \text { is }}$ accepted and $\mathrm{H}_{\text {ois }}$ rejected, which means that all independent variables in the model simultaneously contribute significantly to the dependent variable. Meanwhile, when viewed from the probability value of the F or simultaneous test of 0.001 . This indicates that the probability value $0.001<$ than the significance level (0.05), then the conclusion obtained is $\mathrm{H}_{1}$ received and $\mathrm{H}_{0}$ is rejected. This means that simultaneously the independent variables contribute significantly to the dependent variable.

\section{c. Coefficient of Determination Test}

The coefficient of determination of test results can be seen that the value of $R$ squared results of the test coefficient of determination $\left(\mathrm{R}^{2}\right)$ of 0.2307 . The $R$ squared value of 0.2307 indicates that the dependent variable, namely banking performance, can be explained by the independent variable consisting of the size of the Board of Commissioners, the size of the Board of Directors, the size of the Audit Committee, and the size of the company by $23.07 \%$. While the remaining $76.93 \%$ are influenced by other variables.

\section{Conclusions and suggestions}

Referring to the results of this research, it can be concluded that the variables of Board of Directors Size, Board of Commissioners Size, and Company Size do not contribute significantly and also positively to the variables of banking performance at BPD in Indonesia. Meanwhile, the size of the Audit Committee contributes a negative and significant impact on banking performance at BPDs in Indonesia. Suggestions that researchers can give to the bank in order to prioritize the quality of members so that the company can improve its performance. In addition, small companies do not necessarily have a small ROA value. What needs to be considered is how to get maximum profit by managing assets owned by the company effectively and efficiently so that it has an impact on improving company performance. Meanwhile, further researchers are expected to be able to increase the time period, replace or add other variables that can be tested for their influence on company performance such as NPL, CAR, and or others. In addition, the company's performance can also be proxied in addition to ROA, which is like with ROE. 


\section{Bibliografi}

Akpan, Emmanuel S. B Hodo, R. (2012). Does Corporate Governance affect Bank Profitability? American International Journal of Contemporary Research, 2(7), 1-11.

Alex, M., \& Ngaba, D. (2018). Effect of firm size on financial Performance on banks Case of of Commercial Banks in Kenya. International Academic Journal of Economics and Finance, 3(1), 175-190.

Dany Yadnyapawita, I. M., \& Aryista Dewi, A. (2020). Pengaruh Dewan Direksi, Komisaris Non Independen, dan Kepemilikan Manajerial pada Kinerja Perusahaan Manufaktur di BEI. E-Jurnal Akuntansi, 30(8), 1985. https://doi.org/10.24843/eja.2020.v30.i08.p07

Dewi, A. S., Sari, D., \& Abaharis, H. (2018). Pengaruh Karakteristik Dewan Komisaris Terhadap Kinerja Perusahaan Manufaktur Di Bursa Efek Indonesia. Jurnal Benefita, 3(3), 445. https://doi.org/10.22216/jbe.v3i3.3530

Hendrawaty, E. (2017). Excess Cash dalam Perspektif Teori Keagenan. Anugrah Utama Raharja.

Irma, A. D. A. (2019). Pengaruh Komisaris, Komite Audit, Struktur Kepemilikan, Size, dan Leverage Terhadap Kinerja Keuangan Perusahaan Properti, Perumahan dan Konstruksi 2013-2017. Jurnal Ilmu Manajemen, 7(3), 697-712.

Mashudi, M., Himmati, R., Ardillah, I. F. R., \& Sarasmitha, C. (2021). Financial Distress Prediction in Infrastructure, Utilities, and Transportation Sector Companies 2015-2020. Jurnal Keuangan Dan Perbankan, 25(3). https://doi.org/10.26905/jkdp.v25i3.5858

Megawati, H. (2021). GOOD CORPORATE GOVERNANCE DAN KINERJA KEUANGAN ( Studi Empiris pada BUMN di Indonesia ). 2(2), 102-117.

Pricilia, S., \& Susanto, L. (2017). Pengaruh kepemilikan institusional, kepemilikan manajerial, komisaris independen, dan ukuran dewan komisaris terhadap manajemen laba serta implikasinya terhadap kinerja keuangan pada perusahaan manufaktur yang terdaftar di bursa efek indonesia periode 201. Jurnal Ekonomi, 22(2), 267-285. https://doi.org/10.24912/je.v22i2.226

Puspitowati, N. I., \& Mulya, A. A. (2014). Pengaruh ukuran Komite Audit, Ukuran Dewan Komisaris, Kepeilikan Manajerial, dan Kepemilikan Institusional Terhadap Kualitas Laba. 3(1).

Rahmawati, I.A., Rikumahu, Brady., dan Dillak, V. J. (2017). Pengaruh dewan direksi, dewan komisaris, komite audit dan Corporate social responsibility Terhadap kinerja keuangan perusahaan. Jurnal Akuntansi Dan Ekonomi, 2(2), 54-70.

Sari, T. D., Titisari, K. H., \& Nurlaela, S. (2020). Pengaruh Kepemilikan Manajerial, Komite Audit, Leverage dan Ukuran Perusahaan Terhadap Kinerja Keuangan. Upajiwa Dewantara, 4(1), 1526.

Sudarmanto;, E., \& Dkk. (2021). Good Corporate Governance (GCG) (J. Karim, Abdul; Simarmata, Ed.; Cetakan 1). Yayasan Kita Menulis.

Suharyani, R., Ulum, I., \& Jati, A. W. (2019). PENGARUH TEKANAN STAKEHOLDER DAN CORPORATE GOVERNANCE TERHADAP KUALITAS SUSTAINABILITY REPORT. Jurnal Akademi Akuntansi, 2(1).

Sukandar, P. P. (2014). PENGARUH UKURAN DEWAN DIREKSI DAN DEWAN KOMISARIS SERTA UKURAN PERUSAHAAN TERHADAP KINERJA KEUANGAN PERUSAHAAN (Studi Empiris pada Perusahaan Manufaktur Sektor Consumer Good yang Terdaftar di BEI Tahun 2010-2012). None, 3(3), 689-695.

Wijayanti, S., \& Mutmaimah, S. (2012). Pengaruh Good Governance Terhadap Kinerja Keuangan Pada Perusahaan Perbankan Yang Terdaftar Di Bursa Efek Indonesia. EBA Journal: Journal Economics, Bussines and Accounting, 1(2), 1-15. https://doi.org/10.32492/eba.v5i2.842

Wufron. (2017). Pengaruh Kinerja Keuangan Terhadap Nilai Perusahaan Pada Perusahaan Manufaktur Yang Terdaftar Di Bursa Efek Indonesia. Jurnal Wacana Ekonomi, 16(3). https://doi.org/10.37751/parameter.v4i1.31 